\title{
Hubungan Antara Adversity Intelligence Dengan Work-Family Conflict Pada Guru Wanita Di Sekolah Kalam Kudus Mayang Medan
}

\author{
Elvina, Winida Marpaung, Yulinda S. Manurung \\ Unviersitas Prima Indonesia \\ Email: elvina.wirawan20@gmail.com
}

\begin{abstract}
This study aims to determine the relationship between Adversity Intelligence with Work Family Conflict. The research subject used in this study wer 90 female teachers at the Kalam Kudus School. Data obtained from a scale to measure Adversity Intelligence and Work Family Conflict. Analys of the data use is using Pearson Product Moment Correlation. The results of data analysis showed a correlation coefficient of - $0.715(p<0.05)$ and showed a negative relationship between Adversity Intelligence Work Family Conflict. The results of this study indicate that the contribution of Adversity Intelligence to Work Family Conflict is 51.1 percent, this indicates a very significant relationship between the variable Adversity Intelligence with Work Family Conflict on teachers
\end{abstract}

Keywords: Teachers, Adversity Intelligence, Work Family Conflict

\begin{abstract}
Abstrak
Penelitian ini tujuan untuk mengetaui hubungan antara Adversity Intelligence dengan Work Family Conflict. Subjek penelitian yang digunakan dalam penelitian ini guru-guru Wanita di Sekolah Kalam Kudus sebanyak 90 orang. Data diperoleh dari skala untuk melihat Adversity Intelligence dan Work Family Conflict. Analisis data yang digunakn adalah menggunakn Pearson Product Moment Correlation. Hasil analisis data menunjukan koefisien korelasi sebesr $-0,715(\mathrm{p}<0,05)$ dan menunjukan terdapat hubungn negatf antara Adversity Intelligence dengan Work Family Conflict. Hasil penelitian ini menunjukan bahwa sumbang yang diberikan Adversity Intelligence terhadap Work Family Conflict adalah sebesar 51,1 persen, hal ini menunjukan adanya hubungn yang sangat signifikn antar variabel Adversity Intelligence dengan Work Family Conflict terhadap guru
\end{abstract}

Kata kunci: Guru-guru, Adversity Intelligence, Work Family Conflict

\section{Pendahuluan}

Pendidikan formal merupakan jalur pendidikan sekolah yang tersusun secara struktur dan berjenjangan menenga, dan pendidkan tingi. Pendidkan formal merupkan jalur pendidkan sekolah yang terstruktur dan bejenjang yang terdri atas pendidkan anak usia dini, pendidkan dasar, pendidkan menenga, dan pendidkan tingi. Pendidkan formal terdiri dari pendidkan formal berstatus negeri dan pendidkan formal bersatus swasta. Satuan pendidkan penyelengara, taman kanak-kank (TK), raudatul athfal (RA), sekolah dasar (SD), madrasah ibtidaiya (MI), sekolah menengah pertama (SMP), madrasah tsanawiyah (MTS), sekolah menenga atas (SMA), madrash aliyah (MA), sekolah menenga kejurusan (SMK), madrasah aliyah kejuruan (MAK), perguruan tinggi, akademi, politeknik, sekolah tingi, institute, dan universtas (Neolaka \& Grace, 2015). Sekolah menyelenggarakan aktivtas belajar dan mengajr dengn terima siswa dan memberikn pelajaran kepda para murid sesuai dengan tingkatan, jurusan, dan lainnya. Kegiatan belajar-mengajar di sekolah harus didukung oleh sarana dan prasaran serta bebagai aturan peraturn yang telah dibuat dan ditetpkan oleh pemerintah.

Chinchilla dan Grau, (2002) work-family conflict (WFC) merupakn satu bentuk konflik peran dimana tuntutn pern dari pekerjan terhadap keluarga secara mutual gak dapat disejajrkan dalam beberapa hal. Work-family conflict (WFC) didefiniskan sebagai bentuk konflik antar peran dimna teknan dari peran pekerjaan dan keluarga saling bertentangn (Kahn et al., 1964, dalam Ahmad, 2008).Surekha (2001) menyatakan bahwa Adversity adalah kemmpuan berpikr, mengelola dan mengarakan tindakn tuk membaut suatu pola-pola tangapan kognitif dan prilaku atas stimulus peristiwa-peristiwa dalam 
Yunike Cheria, Gloria Tarafang, Setiyo Wibowo, Calvian Tanur, Aleksander Agung Wijaya, Sri Hartini Psyche 165 Journal Vol 14 No 1 (2021) 67 - 70

kehidupan yang merupakan tantang atau kesulitan. Ditambahkan pula kesulitan yang dihadapi itu mempunya beragam variaa bentuk dan kekuatn dari sebuah tragedi yang besar hinga kelalaian kecil. Stoltz (2000), mendefinisikn bahwa Adversity Intelligence adalah satu kemapuan untuk membat hambatn menjadi suatu peluang keberhasilan capai tujuan. Kesejahteran merupakan hal utama dalam hidup. Kesejahteran dapat diperoleh melalui bebrapa cara, salah satunya dengan bekeja. Setiap manusia pasti mendambakan pekerjaan yang layak, karena pekerjaan yang layak menjamin individu memperoleh kesejahteraan dalam hidupnya. Kesejahteran individu dapat dilihat dari seberapa besar kebahagiaan yang diperoleh individu tersebut. Salah satu cara untuk memperoleh kebahagiaan hidup adalah kesuksesan dalam bekerja. Untuk memperoleh kesuksesan dalam karir, individu dituntut untuk bekerja keras. Bekerja tidak terhindar dari rintangan, dimana rintangan yang dihadapi bermacm-macam, masalahnya adalah bagaimana individu menanggapi rintangan tersebut. Stoltz (2000), mengatakan bahwa kecerdasan menghadapi rintangan (Adversity Intelligence) adalah suatu kelebihan untuk ubah halangn jadi suatu luang keberhasilan mencapai tujuan. Kecerdsan dalam hadapi rintangan liputi dua komponn penting pada tiap konsep mudah, yaitu teori ilmiah dan penerapan dalam kehidupn sehari. Konsep itu sudah diuji cobakan pada ribuan orang dari perusahaan-perusahaan di seluru dunia. Kecerdasan dalam hadapi rintangn dapat ditentukn siapa yang dapt berhasil melampui harapn-harapan atas kinerja dan potensi-potens yang ada akan mampu mengatasi work-family conflict. (Stoltz, 2000). Greenhaus dan Beutell (1985), menjabarkan work-family conflict sebagai bentuk dari konflik antar peran yaitu saat tekanan peran dari kerjaan dan keluarga saling bertentangn sehinga partisipan dalam peran menjadi lebih sulit disebabkn partisipan pada peran lainnya. Pertentang serta tekan yang makin naik antara peran di keluarga dan pada lokasi kerja menyebabkan efektvitas pada peran terhambat oleh kegiatan peran lainya. Work family conflict menimbulkan berbagai masalah yang mempengaruhi kehidupn keluarga dan pekerjan wanita karir tersebut. Sulitnya menyeimbangkan urusan pekerjan dan keluarga dapat menimbulkan konflik pekerjaan-keluarga (work-family conflict), dimana hal pekerjan menggangu kehidupn keluarga dan atau hal keluarga menganggu kehidupan pekerjan yang pada akhirnya dapat mempengaruhi kinerja baik suami ataupn istri yang sibuk kerja. Beberapa penelitian dari para ahli menunjukkan bahwa Work Family Conflict dapat menjadi prediktor untuk memprediksi Adversity Intelligence. penelitian lain yang dilakukan oleh Fitriani (2017) tujuan pada penelitian ini adalah untuk tahu hubungn antar adversity intelligence pada work family conflict pada ibu yang bekeja jadi perawat di RSUD. I. A. MOEIS Samarinda. Hasil penelitian menunjukan bahwa terdapat hubungan negatif yang signifikn antara adversity intelligence pada work family conflict pada ibu yang kerja jadi di RSUD.I.A MOEIS Samarinda dengan hasil korelasi uji Product Moment antar work family conflict dengn adversity intelligence menunjukkan adanya hubungan negatif. Dimana apabila work family conflict tinggi maka adversity intelligence pada ibu yang kerja jadi di RSUD.I.A MOEIS Samarinda rendah, sebaliknya work family conflict rendah maka adversity intelligence pada ibu yang kerja di RSUD.I.A MOEIS Samarinda tinggi.

\section{Metode Penelitian}

Fraenkel, Wallen dan Hyun (2012) menyatakan bahwa populasi merupakan suatu kelompok besar dimana salah satunya diambil untuk mendapatkan hasil tertentu. Populasi sebagai wilayah generalsasi yang terdiri pada objek atau orang yang punya kualitas dan karakter tertentu yang ditetapkn oleh peneliti untuk dilihat dan kemudian diambil kesimpulanya (Sugiyono, 2014). Penelitian ini dilakukan dengan metode kuantitatf (Siswanto, Susila \& Suyanto 2017). Sampel penelitian ini adalah guru-guru wanita yang pengajar di sekolah Kalam Kudus Mayang Medan. Adapun alasan dipilihnya karyawan guna mengontrol variabel work family conflict pada guru yang telah mengajar lebih dari 3 tahun dengan tujuan untuk dapat menganalisis kondisi mengajar guru yang berhubungan dengan penelitian. Penelitian ini melibatkan 90 guru Kalam Kudus Mayang Medan. 
Yunike Cheria, Gloria Tarafang, Setiyo Wibowo, Calvian Tanur, Aleksander Agung Wijaya, Sri Hartini Psyche 165 Journal Vol 14 No 1 (2021) 67 - 70

\section{Hasil dan Pembahasan}

Tabel 1. Karakteristik Subjek

\begin{tabular}{lcc}
\hline Gender & Jumlah & Persentase (\%) \\
\hline Perempuan & 90 & 100 \\
Total & 90 & 100 \\
\hline
\end{tabular}

Tabel 2. Data Deskriptif Adversity Intellegence dan Work Family Conflict

\begin{tabular}{|c|c|c|}
\hline & Adversity Intellegence & Work Family Conflict \\
\hline Skor Minimum & 58 & 61 \\
\hline Skor Maksimum & 159 & 150 \\
\hline Skor Rata-rata & 129,87 & 87,43 \\
\hline Standar Deviasi & 17,99 & 18,14 \\
\hline Kategori Rendah (Persentase) & $5(6 \%)$ & $45(50 \%)$ \\
\hline Kategori Sedang (Persentase) & $16(17 \%)$ & $39(43,33 \%)$ \\
\hline Kategori Tinggi (Persentase) & $69(77 \%)$ & $6(6,67 \%)$ \\
\hline
\end{tabular}

Berdasarkan data pada tabel 1, untuk variabel Adversity Intellegence, 6 persen yang memiliki Adversity Intellegence rendah, terdapat 17 persen yang memiliki Adversity Intellegence sedang, dan 77 persen yang memiliki Adversity Intellegence tinggi. Rata-rata subjek penelitian memiliki Adversity Intellegence tingg.

Dari skala Adversity Intellegence mean empirik sebesar 129,87 dengan standar deviasi 17,99. Hasil analisis untuk skala work engagement diperoleh mean emprik > mean hipoetk yaitu 129,87>102,5 bisa disimpulkan Adversity Intellegence pada subjek penelitian lebih tinggi daripada populasi pada umumya.

Selanjutnya, tuk variabel self disclosure, terdapat 50 persen yang memiliki Work Family Conflict pada kategori rendah, 43,33 persen yang memiliki Work Family Conflict pada kategori sedang, dan 6,67 persen yang memiliki Work Family Conflict pada kategori tinggi. Berdasarkn penjelasan tersebut maka bisa disimpulkan yaitu rata-rata subjek penelitian memiliki Work Family Conflict rendah.

Dari skala Organizational Climate yang disi subjek, diperoleh mean empirk sebesar 87,43 dengan standar devias 18,14. Hasil analisis untuk skala Organizational Climate diperoleh mean empirik < mean hipotetik 87,43 < 110 maka bisa disimpulkan Work Family Conflict terhadap subjek penelitian lebih rendah dari populasi pada umunya.

Berdasarkan hasil pengujian linearitas, dapat dilihat nilai sig sebesr 0.000 yang mana $p<0.05$, sehinga dapat disimpulkan bahwa kedua variabel memiliki hubungan linear dan telah memenuhi syarat untuk dilakukan analisis Pearson Product Moment Correlation

Tabel 3. Hasil Uji Hipotesis

\begin{tabular}{lcccc}
\hline Anslisis & $\begin{array}{c}\text { Pearson Product } \\
\text { Moment }\end{array}$ & $R$ & $R$ Square & $\begin{array}{c}\text { Std. Error of the } \\
\text { Estimate Koefisien }\end{array}$ \\
\hline Koefisien & -.715 & .511 & .505 & 12,76364 \\
\hline Sig & 0,000 & & & \\
\hline
\end{tabular}

Sesuai dengan hasil uji hipoteis dengan Pearson Product Moment Correlation pada tabel 3 menunjukan adanya korelasi negativ yang signifikn antar Adversity Intellegence dengan Work Family Conflict. Karena koefisien korelasi sebesar $-0,715$ berada pada rentang 0,600 - 0,799, maka korelasi ini dikategorikan pada hubungan yang kuat (Sugiyono, 2007). Dari hasil perhitungn tersebut, maka 
Yunike Cheria, Gloria Tarafang, Setiyo Wibowo, Calvian Tanur, Aleksander Agung Wijaya, Sri Hartini Psyche 165 Journal Vol 14 No 1 (2021) 67 - 70

hipotesis yang diajukan dalam penelitian ini menunjukan ada hubungn negativ antar Adversity Intellegence dengan Work Family Conflict pada guru Kalam Kudus Kota Medan diterma dan bisa dinyatakn ada hubungn negativ yang sedang dan signifikan antar Adversity Intellegence dengn Work Family Conflict.

Dalam penelitian ini diperoleh kofisien determinasi $\left(\mathrm{R}^{2}\right)$ sebesr 0,511 . Berdasarkn hasil tersebut, dapat disimpulkan bahwa sumbangn 51,10 persen Adversity Intellegence memengarui Work Family Conflict dan selebihnya sebesar 48,9 persn dipengaruh oleh hal lain yang tidak diteliti pada penelitian ini, seperti, religius dan sikap orang tua. Dengan demikian, dapat diambil kesimpulan bahwa semakin tinggi Adversity Intellegence yang dimiliki guru Kalam Kudus Kota Medan maka makin rendah Work Family Conflict yang mereka miliki. Sebaliknya, makin rendah Adverity Intellegence yang dimiliki guru Kalam Kudus Kota Medan maka semakin tinggi Work Family Conflict mereka.

\section{Kesimpulan}

Hasil uji Product Momnt dari hipotess membuktkan bahwa terdapt hubungan negativ antar variabel Adversity Intellegence dan variabel Work Family Conflict dengan kofisien korelasi Parson Product Momnt sebesar $-0,715$ dan dengan $\mathrm{p}=0.000(\mathrm{p}<0.05)$, dan nilai $R$ square $\left(\mathrm{R}^{2}\right)=0.511$. Hasil penelitian ini menunjukan bahwa sumbangan yang diberikan variabel Work Family Conflict kepada variabel Adversity Intellegence adalah sebesar 51,1 persen, selebihnya 48,9 persen dipengaruh oleh faktor lain yang gak diteliti, contohya konsep diri, religiusitas, juga peran orangtua.

\section{Daftar Rujukan}

[1] Chinchilla, N \& Grau, M. 2002. The Work-Family Balance in Light of Globalization And Technoiogy [E-book] (Update 08 Mar 2016) Tersedia di:

https://books.google.co.id/booksid=98I3DwAAQBAJ\&pg=PA75\&dq=Chinchilla+\%26+Grau+2002\&hl=en\&sa=X\&ved=0ahUKEwitq sSvj6vfAhXJK48KHQyfDNwQ6AEIKDAA [Accessed 07 Oktober 2018]

[2] Fitriani, 2017. Jurnal Psikologi. Hubungan Antara adversity intlligence dengan work-family conflict pada Ibu yang Bekerja Sebagai Perawat RSUD. I.A. Moeis Samarinda, 02 (03)

Tersedia di: http://journal.ac.id/Psikologika/article/view/84e41/7168-a09392 [Accessed 08 Oktober 2018]

[3] Frone, M. R. 1992. Handbook of occupational health psychology. [E-book] (Update 08 Mar 2016)

Tersedia di:

https://books.google.co.id/books?id=VgfBRAAACAAJ\&dq=Handbook+of+occupational+health+psychology\&hl=en\&sa=X\&ved=0ah UKEwj7mbrSjqvfAhUKP48KHYIJCXsQ6AEIKDAA [Accessed 01 Oktober 2018]

[4] Grenhaus, J.H. \& Beutell, N.J. 1985. Sources of conflict between work and family roles. [E-book] (Update 05 Apr 2017) Tersedia di:

https://books.google.co.id/books?id=05CJYdZHBWIC\&pg=PA95\&dq=Sources+of+conflict+between+work+and+family+roles\&hl=en \&sa=X\&ved=0ahUKEwjV1auNjqvfAhUXeisKHS2DBJwQ6AEIKDAA [Accessed 05 Oktober 2018]

[5] Kahn, R.L., Wolfe, D.M., Quinn, R.P., Snoek, J.D., Rosenthal, R.A. 1964. Ocupational Stres: Studies in Role Conflict and Ambigutiy [Ebook] (Update 05 Apr 2017)

Terseida di:

Ahmad,+2008+dafpus\&hl=ban\&sa=X\&ved=0ahUKEwjPq8KBgvneAhWQinAKHROND9gQ6AEINDAC\#v=onepage\&q\&f=false

[6] Moleong, L.J. 2001. Metodologi Penelitian Kualitatif. Bandung. Remaja Rosdakarya.

[7] Soewadji, J. 2012. Pengantar Metodologi Penelitian. Jakarta : Mitra Wacana Media Tersedia di : http://www.koran-sindo.com [Accessed 15 Maret 2019]

[8] Marton,N., 2011. Metode peneliti kuantitati analisi isi dan analisis data skunder. Jakarta. PT Raja Grafindo Persada

[9] Sugiyono. 2010. Metode Penelitian Pendidikn Pendekatn Kuantitatif, kualitatif, dan R\&D. Bandung: CV. Alf 